\title{
Risky, early, controversial. Puberty in medical discourses
}

\author{
Donatella Cozzi ${ }^{\text {a, }}{ }^{\text {, }}$, Virginie Vinel ${ }^{\text {b }}$ \\ a Department of Human Sciences, Udine University, Piazza Petracco 8, 33100 Udine, Italy \\ b Department of Sociology, Franche Comté University, 30-32 Rue Mégevaud, CS 81807, 25030 Besançon Cedex, France
}

\section{A R T I C L E I N F O}

\section{Article history:}

Available online 11 November 2014

\section{Keywords:}

France

Italy

Precocious puberty

Early puberty

Medical discourse

Gender

Health professionals

\begin{abstract}
A B S T R A C T
This article comes within the compass of a research program (entitled CorAge. Bodily Experiences and AgePassages among 9-13 year-olds (ANR-09-ENFT-017) conducted between 2009 and 2013 about the emergence of a "new" age in life -"preadolescence"- as instanced in France (Alsace, Lorraine) and Italy (Venetia). The impressive amount of references to "early puberty" and "precocious puberty", in a context of feeling of a premature end of childhood, led us to make an in-depth study of this issue: first, through an analysis of international and French and Italian medical journals; second, through interviews with health professionals. Following the thesis of Foucault, we assume that the discourses on puberty timing participate of classifications of the child body drenched with moral representations of childhood, especially on gender and age issue. Our results: the question of whether a secular trend in puberty timing even exists continues to be debated between American and European scientists. Second, the terms "puberty", "precocious puberty", "early puberty" have been used to indicate a variety of puberty markers, increasing confusion. A controversy has focused on early breast development in girls, because this attribute is questioning the order of ages and gender. Moreover, psychosocial factors presented as accelerating early puberty, do not demonstrate the relation between earliness and risk behavior. The literature, as it is moved by the female precocity, creates a medical category to objectify the complex and flexible process of puberty and invent female child precocity. These differences between American and European scholars and the interviews with French and Italian health professional show a gap between the international literature and practitioners, clinicians and nurses who regularly work with children: they neither find pubertal advancement, nor increase of "true precocious puberty", although they share concerns about premature feminization of girls (France) or environmental toxicity (Italy) on children.
\end{abstract}

(c) 2014 Elsevier Ltd. All rights reserved.

\section{Introduction}

This article comes within the compass of a research program conducted between 2009 and 2013 on the subject of the emergence of a "new" age in life - preadolescence - as instanced in France and Italy. The program entitled CorAge. Bodily Experiences and Age Passages among 9-13 year-olds (ANR-09-ENFT-017) studies and questions the representations and practices of the different types of social actors concerned by children in this age group: parents, the peers, professionals in the education and health sectors. The study centers on three regions geographically close as well as comparable in socio-economic terms: Alsace, Lorraine and Venetia (Diasio \&Vinel, 2014). This article focuses on the health and medical aspects of the CorAge project: the controversy on both the average

\footnotetext{
* Corresponding author.

E-mail address: donatella.cozzi@uniud.it (D. Cozzi).
}

onset of puberty and precocious puberty (when children show the development of sexual traits before the age of 8 for girls and 9 for boys).

\section{From childhood to adolescence: the state of the art}

The state of the art on the passage from childhood to adolescence has highlighted two trends. Some scholars focus on a broad floating among ages (Meyrowitz, 1985; Galland, 2008), a shortening of childhood and an earlier entry into adolescence concomitant with the consumption of products looked at with ambiguity (Buckingham, 2000; Cook and Kaiser, 2004; Bouchard and Bouchard, 2003). The feeling of a premature end of childhood is amplified by the public agencies in a number of countries in Europe and North America through reports on the early sexualization of children - above all, girls (Duquet and Quiéniart, 2009; Bailey, 2011; Jouanno, 2012). Other sources, such as the international 
medical data bases and articles on puberty in the French and Italian press, show that "puberty" is frequently associated with the terms "precocious" and "risk".

The impressive amount of references to "precocious puberty" led us to make an in-depth study of this issue. This article presents the results of our inquiry.

Our aim is first to determine what is considered as "normal" and "abnormal" in terms of puberty, and whether the knowledge about puberty is consolidated or under debate. Michel Foucault's (1999) concepts of normalization will be called on in this article to show how the set of discourses on puberty timing and early puberty participate of classifications of the child body drenched with moral representations of childhood.

We shall then examine the risks and diseases highlighted in medical publications in connection with the early onset of puberty and precocious puberty. We shall not be charting the reality of early puberty or the increasingly young age at which precocious puberty occurs, nor embarking on an exhaustive analysis of the international literature on puberty; rather, drawing on a specifically selected sample of publications, our focus will be on the anthropological issues arising from inquiry into precocious puberty today, more particularly among young girls. Our last section will focus on showing and interpreting the contrast between the danger warnings put out in medical literature and the lack of concern among the practitioners we met in France (Alsace, Lorraine) and Italy (Venetia).

The article follows the works of Corsaro (1997), James and Prout (1990, 1998), Armstrong (1995), Moulinié (1998), Turmel (2008), Diasio (2012): these scholars reveal how the development steps of childhood are but historical, social and medical constructions which denaturalize the child timings. It also draws on a critical approach to science and biomedicine, and shows that, in time and place, theories are not compelling only by virtue of their objective scientific truth alone, but also by their interrelationship with factors deriving from social and historical conditions (Foucault, 1976; Callon and Latour, 1991; Bourdieu, 1997; Fabiani, 1997; Lock and Nguyen, 2010). Critical social science perspectives show how gendered representations of the masculine and feminine have determined not only the objects of research and the imagery and style of writing, but also the scientific and medical results (Martin, 1992, 2007; Laqueur, 1990; Kraus, 2000; Gardey \& Löwy, 2000). The social sciences have endeavored to deconstruct past and present medical representations of a number of physiological changes experienced by women: menopause (Kaufert and Gilbert, 1986; Lock, 1993; Diasio \&Vinel, 2007), pre-menstrual syndrome (Martin, 1992), pregnancy (Löwy, 2009; Neiterman, 2010). Puberty among girls has been mainly treated in terms of menarche: whereas cultural and historical representations of menarche are well documented (Chebel, 1984; Britton, 1996; Brumberg, 1997; Fingerson, 2005; Mardon, 2009), publications on the male experiences and representations of puberty in Europe and North America are wanting (Mora, 2012). As a consequence, little research has been carried out in the social sciences on medical and epidemiological descriptions of puberty or on health care for pubertal children (Roberts, 2013; Cozzi, 2013, 2014; Vinel, 2014b). A further aim of this article is to help redress this balance.

\section{Sample and methods}

The documentary research into the medical literature dealing with the early onset of puberty has been carried out by phases. During the exploratory phase, we used key-words to look through the following medical databases: Scopus, eMedecine, Medline and the Directory of Open Access Journals (DOAJ). The period under examination was from 1969 (the year of publication of Marshall and
Tanner's reference article on the stages of pubertal development among girls: Marshall and Tanner, 1969) to 2009. As our searches progressed, we got aware of the degree of controversy surrounding the timing of puberty onset: this prompted us to create an anthology of articles published on the subject in the journal Pediatrics between 1997 (the year of publication of a controversial article on early puberty, Herman-Giddens et al., 1997) and 2012. The antology resulted from both individual and joint full reading and analysis of such articles. With regard to French sources, our starting point was the INSERM report Croissance et puberté. Evolution séculaire, facteurs environnementaux et génétiques (Growth and Puberty. Secular Trends, Environmental and Genetic Factors, 2007a) together with its abridged version (2007b). Then we created an annotated bibliography based on specialist journals on health, such as Archives dePédiatrie (2005-2010) and Soins Pédiatrie/puériculture (2005-2009). A systematic web exploration by key-words through the search engine egora-doc (2005-2010) produced a further 11 articles. As for the Italian medical journals we referred to: the Italian Journal of Pediatrics, Quaderni ACP, Medico ebambino, Pediatria. From these, we kept 10 articles for analysis. The 110 selected articles deal with: the timing and stages of pubertal development and menarche onset; discussions on the increasingly early age of puberty onset; causes and effects of precocious puberty, along with the social and psychological dimensions. We also checked the pertinence of our international medical and epidemiological references against the article by Parent et al. (2003) and Euling's compilation (Euling et al., 2008). Following this phase, we carried out both semi-directive and group interviews with 61 health professionals in Alsace, Lorraine and Venetia: our interviewees represented a mix of branches in the health sector, and included both men and women working in different locations (both urban and rural areas) and types of organization. The aim of our survey was to meet professionals working with children aged 9-13 in a context lacking in anthropological and sociological studies on the medical assistance during puberty in France and Italy. In East France, we carried out semi-structured interviews with 22 among general practitioners, medical specialists (endocrinologists, pediatricians, psychiatric consultants), school nurses and social workers. The focus-group included 17 among general and school practitioners, recruited through the professional directories of Alsace and Lorraine. In Venetia, the focus group and the single contact involved 22 among medical specialists, psychologists and social workers recruited at the Local Sanitary Unit (ASL) of Venice, Belluno and Feltre: the last two are located in an Alpine area. After a preliminary phone contact, all the professionals agreed to be recorded and have their comments published anonymously. Ethical approval for research was obtained.

The 61 interviews were processed through Nvivo ${ }^{\circledR}$ (8th edition), a qualitative data analysis computer software that organizes non numerical or unstructured data. A multiple close reading of all interviews generated a code that recorded puberty and developmental precocity, the relations between professionals and child patients, and the children bodily appearance. In addition, we examined variations within and across groups, and we compared the responses by position in the medical hierarchy (general practitioners/hospital endocrinologists, school nurses/pediatricians) and by gender.

Medical and health care in France and Italy are organized along different lines: in France, children up to 6 years of age have their compulsory medical examinations paid for by the National Health Service. These either can take place in a national health clinic (Protection Maternelle Infantile, namely the Mother and Child Care Units) or be carried out by a pediatrician or a general practitioner in the private sector. Apart from two examinations organized by school nurses under the schools' health service program at the ages 
of $8-9$ and $10-11 / 12$, children have no other compulsory medical examinations. Parents can arrange consultations with a general practitioner or a pediatrician if they wish to, though in rural areas pediatricians are just a few. In Lorraine and Alsace, there are other public health services whose target are adolescents: for example, advisory centers on contraception, the CAMPA (a medicopsychological information center for adolescents), the Maison des adolescents (an information center for adolescents), and a youth information center about sexuality and reproductive health in Strasbourg (Info-Ado, General Hospital).

In Italy, new-born children are registered with a general pediatrician with special training in pediatrics. Parents have a free choice of general practitioner, and children remain on his/her register until the age of 14 . There are very few practicing pediatricians in rural and mountainous areas. This primary level of care, the Distretto Sanitario, is backed up by vaccination unit, childhood psychiatric care, family planning units and services for adolescents and the young (the Consultorio Giovani). These latter services provide social and psychological support, as well as counseling for persons in need, and organize information sessions and events. A second level of care includes hospitals and Children's Emergency Care Unit. The general pediatric and the Distretto Sanitario act as filters for hospitals and specialized services in the event of emergency or need for intensive or longer-term care. There are no school doctors or nurses: in Italy, the local social and health services play a major role in providing child health care - that is why we chose to meet a wide range of professionals in these health sectors.

\section{Early puberty: gender and age timing at stake. A literature review}

Since the end of the 1990s one phenomenon has brought more and more children under growing medical attention: that is, the earlier onset of puberty - mostly among young girls. This section summarizes the main features of this trend as they emerged from the articles selected.

Thelarche, the onset of female breast development, is characterized by tender nodules of firm tissue centered on the areolae; these nodules are usually appreciable by palpation before they are by visual inspection. Adrenarche is the onset of androgendependent signs of puberty (pubic hair, acne, and adult body odor). Menarche is the onset of menstruation.

By convention, normal (that is, average) puberty begins between the ages of 8 and 12 in girls and between 9 and 14 in boys in Europe and North America. A century-long trend reduced the age of menarche from 17 to about 12 years: its variations depend on country, social categories, ethnicity or national origin, nutritional factors (Parent et al., 2003; Carelet al., 2002; INSERM, 2007a; Euling et al., 2008). The criteria for defining the five stages of puberty in boys and girls proposed by Marshall and Tanner in 1969 and 1970 remain the standard.

Endocrinologists subdivide precocious puberty into two distinct categories. The former is gonadotropin-dependent precocious puberty, which involves the premature activation of the entire hypothalamic-pituitary-gonadal (HPG) axis: this is also called central precocious puberty (CPP) or "true precocious puberty". The latter is gonadotropin-independent precocious puberty, peripheral puberty or precocious pseudopuberty (Brauneret al., 2005; Kaplowitz and Kemp, 2013; Sinha and Kemp, 2013).

By statistic convention children whose secondary sexual traits show before the age of 8 (for girls) and 9 (for boys) are said to suffer from early or precocious puberty. Such convention about the average onset of puberty has been brought into doubt since the end of the 1990s by a number of American studies that claim thelarche and adrenarche may occur at a very early age.
The controversy arose in 1997 when a team from the University of North Carolina (Department of Maternal and Child Health, School of Public Health), directed by Marcia Herman-Giddens et al. (1997), published an article analyzing the results of a study by the Pediatric Research in Office Settings network (PROS) on the pubertal development of 17,077 girls between the ages of 3 and 12 . This stated that breast and pubic hair growth was occurring at a significantly earlier age than the one announced in previous studies, particularly among African-American girls (10 years of age for White American girls, and 8.9 for African-American girls): on the other hand, the age of menarche onset remained unchanged (respectively at 12.8 and 12.1 ).

The study was given considerable exposure in the medical world and the media: it initiated a series of articles and researches on the subject both in Europe and America (Euling et al., 2008 compiled a register of 52 American articles post-1997), and it gave rise to discussions and controversies which continue even today (Biro et al., 2013). Between January 1997 and March 2013, no less than 27 articles and author-reader exchanges on the subject were published in the journal Pediatrics alone. Kaplowitz and Oberfield (1999) even suggested lowering the conventional age of adrenarche and thelarche to the age of 7 for Caucasian girls and 6 for African-American girls.

However there was no general agreement over such statements: Parent and colleagues in Endocrine Review (2003) made a critical analysis of 280 references about puberty timing on a world-wide level between 1942 and 2003, and found no evidence of any general lowering of the age of puberty onset among girls in the West since the 1960s. The only European study -a Danish one-on pubertal stages clinically assessed thanks to Marshall and Tanner's criteria (Juul et al., 2006), concluded that breast development occurred earlier than before, whereas the age of menarche onset remained unchanged and puberty occurred much later in Denmark than in the USA: "At present, the figures from Europe are not as drastic as those seen in the US, although the most recent studies indicate that approximately $5 \%$ of white girls have onset of breast development before 8 years of age" (Sørensen et al., 2012: 140).

In 2001, Herman-Giddens and her team published an analysis of the PROS study. Compared with the findings of earlier studies (which respectively referred to Caucasian, African-American and Mexican-American boys) puberty at stage 2 was occurring at an earlier age: pubic hair growth was reported at $12,11.3$ and 12.6 years of age and testicular development at 10.1, 9.5 and 10.4. This study attracted very little comment and generated little new research (Karpati et al., 2002; Goldstein, 2011).

A few years later, the US Environmental Protection Agency (Euling et al., 2008) issued a paper synthesizing the specialists' discussions on American puberty timing data between 1940 and 1994. Most of specialists agreed on a trend towards earlier onset of puberty, particularly among African-American girls - yet a minority disputed on this due to a methodological incompatibility between the earlier and later studies. All agreed, however, that there were "ethnic" and "racial" differences, and that there was a lack of information on boys' puberty timing.

The large number of publications and discussions on puberty shows that the subject had clearly become a public health issue in the USA. Medical knowledge on puberty, however, was hardly standardized; and the several, even contradictory types of discourse showed the tensions between researchers in Europe and America over defining norms for the child's developing body (Fassin and Memmi, 2004).

The idea of earlier onset of puberty spread at the turn of this century, particularly in the 2010s, in both French-speaking countries and in Italy - when the media and medical digests picked up on the most alarmist medical papers about the risks of a 
phenomenon they quickly equated with "precocious puberty": "Concerns over precocious puberty in young girls" (Agence FrancePresse, La Presse, 2001), "Young American girls are growing up earlier" (Le Monde, 8/9/2010), "Little girls, ripe before their time. The psychological risks of precocious puberty" (Le Monde, 11/ 21-22/2010), "Warnings on precocious puberty" (Le Point, 8/9/ 2012), "Montpellier: more warnings on precocious puberty" (Midi Libre, 5/2/2014).

Yet, in France and Italy, there are no statistical studies on the stages of pubertal development in girls and boys after the Marshall and Tanner scale $(1969,1970)$ - the only existing studies being on the average age of menarche onset (La Rochebrochard, 1999; Gaudineau et al., 2010; Gasparini et al., 2005; Rigon et al., 2012). In Italy, a first study found an average menarcheal age of $11.5( \pm 1.6)$ out of a sample of 351 girls - but the authors also noted that the girls' puberty age was not different from their mothers' (Gasparini et al., 2005). But, in 2012, the Italian Journal of Pediatrics produced up-to-date information on the menstrual pattern of 4992 Italian girls at secondary school: the mean age at menarche was 12.4 ( \pm 1.3) years. In France, on the basis of the international survey "Health Behavior in School-aged Children", Gaudineau et al. (2010) reported a median menarcheal age of 12,8 years. The authors argue that the US data can't be transposed to France, and express doubts about the pertinence of using those data for their study. Nevertheless this led a number of French researchers (Pienkowski and Granjean, 2008; Cartault et al., 2008) to transpose the American findings to the French context, with little critical sense. For example, in some studies the category "African-American girls" has been replaced by the term "girls of African origin", which is, actually, an amalgamation of two historically, though very different types of population: on the one hand, the African Americans enslaved in the United States, and their descendants; on the other hand, the Sub-Saharian migrants to France and their descendants (Vinel, 2014a).

Reference to the issue of precocious puberty has come more specifically from two teams of specialists in the South of France, who noted a growing number of little girls entering puberty before the age of 8: "We analyzed all the cases of precocious puberty recorded in our offices over the last twenty years. For the same number of consultations, 3500 per year, we have gone from 8 cases of central puberty and 8 cases of peripheral puberty in 1993 to 50 cases of central and 60 of peripheral puberty today", said Charles Sultan, a Head of a pediatric endocrinology service (Le Midi Libre, 5/ 5/2014).

In France and Italy, two contradictory tendencies are at play. On the one hand, the media echo the analyses of both medical papers and teams of pediatricians or endocrinologists who highlight today's earlier age of breast development: this generates a discourse that deplores the premature end of childhood for these girls. On the other hand, the same media veil the studies that underline the stability of the age of puberty onset.

What do these discussions tell us? First, we feel their proportions reflect a "moral panic" (Cohen, 2004) around the representations of the child's body, the girl's body in particular: as a matter of fact, both the medical world and the media single out girls whose body does not conform to girl's body as is the expected, nonsexualized body at 6-7 years of age. The wide array of discourse and practices analyzed by the CorAge team is totally in line with these medical alerts: stricter school rules on revealing clothing (Voléry, 2014), government reports on how to protect children from supposedly erotic images, practices and consumer products (Duquet and Quiéniart, 2009; Bailey, 2011; Jouanno, 2012), the worries of parents and educational professionals caught up in a movement whereby "A condition, episode, person or group of persons emerges to become defined as threat to societal values and interests; its nature is presented in a stylized and stereotypical fashion by the mass media; the moral barricades are manned by editors, bishops, politicians and other right-thinking people; socially accredited experts pronounce their diagnoses and solutions" (Cohen, 2004: 1).

Secondly, precocious genital development in AfricanAmerican boys goes as unmentioned (in France and Italy) as precocious breast development in girls is focused in discussions. Through their visible physical attributes, these girls challenge the normalization of age and gender (Rennes et al., 2009; Diasio \&Vinel, 2014) through the normalization of the body (Foucault, 1999; Turmel, 2008). As Roberts (2013) says, discussions on the age at puberty got embroiled with those on the assumed precocious sexualization of girls and the resulting moral strictures in academic and governmental spheres. Discourse here tries to reduce the problem but, in focusing attention on the child's body and defining it as a medical condition (Foucault, 1976), it turns that body back into a problem. Puberty in boys does not attract such a superabundance of comment: supposedly, because the male onset of puberty (testicular volume) has neither the same visibility nor the erotic signification of female one (breast development) - which does not prompt authorities to act or speak.

In the absence of reliable data from European sources, work on the subject has also shown disagreement over the appropriateness of transposing data from the US: some use the data to support their clinical observations (Pienkowski and Granjean, 2008; Cartault et al., 2008); others contest their validity given the differences between the populations under study and the results (even interim) obtained (Gaudineau et al., 2010; Sørensen et al., 2012).

Yet such debate highlights the weakness of European research into puberty - along with the implications and difficulties in turning such a complex, heterogeneous, changing phase of physiological transformations into a public health issue. The state of the art thus requires further study, in order to bring out the professional and institutional variations (let alone, the regional differences) that affect the French and Italian approaches to the issue.

Finally, the situation created by several contradictory studies is confused. After Kaplowitz (2004), if the "normal" (i.e. statistical) age of girls' and boys' puberty onset has lowered, then there is no need to worry or to medically treat children entering puberty at the age of 7 or 8: yet the cause of concern in the medical contexts is triggered right by the health and social risk associated to early puberty.

\section{Precocious puberty as a disease: an analysis of conceptualization of risks}

As mentioned above, there is considerable diversity in the speed of pubertal changes (Grumbach and Styne, 2003; Kaplowitz and Oberfield, 1999; Palmert et al., 1999; Palmert and Boepple, 2001; Bruni et al., 2001). Disturbances of the hypothalamus or higher neurologic centers can result into an abnormal release of $\mathrm{GnRH}$, the growth hormone: whereas gonadotropin-independent sexual precocity can arise from a variety of anatomic or functional lesions. As already said, precocious puberty can be classified as "central", or gonadotropin-dependent, and "peripheral", or gonadotropinindependent (Buck Louis et al., 2008). Medical literature considers premature thelarche and premature adrenarche as either partial forms of precocious puberty (Buck Louis et al., 2008) or as a reflection of normal pubertal physiology, though this occurs at an earlier age (Golub et al., 2008). Many children with central precocious puberty require treatment solely to delay additional maturation: this therapy uses hormones to stop the onset of puberty and 
wait for the appropriate physiological age. Stop-and-go, fermare $e$ partire (It.), démarrer ( $\mathrm{Fr}$.). The endocrinologists' language in interviews describes a partially autonomous mechanism, whose effects are visible whereas the causes are hardly known. "How to stop it" is already possible: "why it selectively starts" is not understood yet. Vincenzina Bruni, among the Italian endocrinologists long studying precocious puberty in children, states: "We explain children we have to stop their development, give them a long treatment with regular check-ups - till, one fine day, we finally tell them they are allowed to grow. Our message is contradictory" (personal communication, 10/26/2012).

According to literature, risks related to early puberty may be categorized in three core groups: risk for the development of diseases, risks deriving from environmental influences, and risks related to behavioral disorders. About the links between early puberty and risks for the development of diseases, children who have markedly accelerated skeletal maturation may have impaired adult stature (Sopher A.B. et al., 2001; INSERM, 2007a; Maroteaux, 2008). A history of precocious adrenarche (PA) in girls is a clear indicator of an increased risk of a metabolic syndrome and/or ovarian hyperandrogenism/PCOS in adulthood (Ibañez et al., 2000). PCOS is a complex disorder characterized by infertility, hirsutism, obesity, and menstrual effects (oligomenorrhea, amenorrhea, anovulation). Other increased risks of complications from these changes in adults are obesity, type 2 diabetes, dyslipidemia, cardiovascular disease, infertility. Girls who exhibit these features are frequently obese, and one study (Dimartino-Nardi, 1999) examined their AfricanAmerican or Caribbean Hispanic origin. Another interpretation of the data is that PA (and perhaps premature menarche) is simply another clinical manifestation of some metabolic syndrome. In this regard PA like metabolic syndrome is often preceded by low birth weight (Ibañez et al., 2000, 1998): a combination of PA and low birth weight increases risk for developing the adult disorders outlined above. Low birth weight associated to obesity also points to some socio-economic features that remain uninvestigated - such as mother and/or family socio-economic census, effects of deprivation and food shortages, toxic exposures of fetus, healthy food availability during pregnancy and childhood.

Deprivation and unhealthy food are much more frequent in "lower-resource countries" than elsewhere. From this point of view discourse about puberty recalls two of the most relevant features concerning control of female fertility and birthing, and nutrition. "At these vital nodes where individual and collective wellbeing intersect, biology emerge[s] as a standard for intervening on bodies and populations" (Lock and Nguyen, 2010: 147).

The age of puberty has historically been used as a measure of health status of peculiar populations, and an improvement in nutrition has been related to it. If the hypotheses on the recent puberty timing are controversial, one prominent evidence supports environmental influences on pubertal onset (Buck Louis et al., 2008). The US Environmental Protection Agency, the National Institute of Environmental Health Sciences and the Serono Symposia International sponsored a multidisciplinary expert panel to identify potential environmental factors of concern. In the review published in 2008 (Buck Louis et al., 2008) the environment is defined as "the sum of all external conditions that affect life, development, and survival of an organism" (www.epa.gov/ ocepaterms/eterms.html). By extension, an environmental factor is defined as a non-genetic factor: as a consequence, the weight of actual evidence is focused on the exposure to endocrine-disrupting chemicals and body size in relation to puberty timing (Euling et al., 2008). The assessment of action of endocrine-disrupting chemicals urges caution given the "highly interrelated and time-dependent nature of pubertal onset and progression as orchestrated by gonadal hormones under the control of gonadotropins. In the presence of exogenous endocrine-active agents, pubertal markers can be independently induced or blocked so that they are not necessarily in synchrony with centrally-regulated pubertal maturation" (Buck Louis et al., 2008: S196).

The most investigated source of timing alteration is the environmental exposure to persistent halogenated organic chemicals such as PCBs (DDT/DDE), brominated flame retardants, dioxin, hexaclorobenzene (HCB), endosulfan, and heavy metals (see Buck Louis et al., 2008 for a review). Other studies have examined the exposure to phthalate esters (Colon et al., 2000) and topical application of lavender and tea tree oils (Henley et al., 2007). A positive relation between body fat and the onset of puberty is often pointed out (Herman-Giddens et al., 1997; Berkey et al., 2000). As a matter of fact, the impact of obesity in children with desultory progression can be considerable: breast development may occur, though secondary to local estrogen production. Medical literature focuses on BMI and body size measures as the implicit results of dietary and physical practices. On the contrary, the social attention is devoted to causes: polluted food as a risk for health; food adulteration (such as meat from hormone-treated animals or products from contaminated farms); and children's/adolescents' dietary habits based on junk food. Medical literature and social attention join in spreading a social alarm rapidly echoed by the media - and the screamer in the Italian national newspaper La Stampa ("Early puberty caused by junk food", 11/05/2012)is uncritically echoed in Italian pediatric journals, such as Pediatria and Medico e Bambino. Earlier maturation factors presented by this article in La stampa are too handily exposure to sexual images in the media and in the net and, quoting Marcia Herman-Giddens' study, obesity and a nutrition too rich in fats. The mention to sexual images as a stimulus for earlier maturation appears as a moral worry about inappropriate imagery for childhood, and this is believed to operate bodily changes, especially in girls. The 'toxic environment' surrounding girls and boys is magnified by the plethora of icons and models of an adult's life representation - such as sex, fitness, consumption.

A social criticism emerges from this translation of consequences into causes, and one in particular: junk food. Precocious puberty as a disease is an uncommonly observable fact, yet junk food may expose all children to the risk to develop it. Obesity is conceived as an environmental factor of disease: the children are being raised in a "toxic environment" in which the food industry promotes inexpensive, handy, high-density and low-nutrient food. Indeed, as de Vries (2007) and Moffat (2010) point out, there has been a subtle shift in the medical literature in the characterization of obesity as a risk factor for a number of diseases. For children, the use of the BMI is more complicated in that the distribution and amount of body fat changes as children's bodies grow and develop (Moffat, 2010). The so-called "epidemics of obesity" promises an intense biomedicalization: de Vries argues that we socially tend to medicalize what we find morally unacceptable. So, which frame should we choose? We could treat early puberty as an environmental problem that is in part fueled by a "toxic food environment". Or we might link it to the consumption of material goods, marketing politics, inequalities in food allocation. Less attention is devoted to chronic malnutrition during childhood and severe protein-energy malnutrition - though both delay puberty in girls and boys. But pubertal delay "is constitutional, representing a transient delay in sexual development that is a variant of normal" (Buck Louis et al., 2008: S195).

Last but not least, risk factors for adolescent and adult onset of diseases are associated to psychosocial matters. The timing of puberty has long been a topic of research for psychologists and psychiatrists. Some of these studies examined children with clinically precocious or delayed puberty, but most of them studied general populations assessed for puberty timing in a variety of ways. Here 
the risk associated to the very early development is converted into the risk of developing behavioral disorders. The link between precocious puberty and behavioral disorder lays in both secondary sexual traits and a more mature body habitus than others in their age range. The assumption that a more mature-appearing child will behave in a more mature manner is flawed: both because the preadolescent is unlikely to demonstrate such behaviors, and because this is often an adult projection on children individual perception of changes. Through this adult gaze, the girls' body is sexualized, generating the haunting figure of the so-called Lolitas. As the studies vary in their purpose and historical era, sample size and design, social context and method of assessing puberty, general conclusions are difficult to present.

Studies associated with large-scale cohorts of adolescents (in Finland, Kaltiala-Heino et al., 2003a,b,c, 2001, 2003; in Britain, Williams \& Dunlop, 1999; in Norway, Wichstrøm, 1995) have shown that pubertal timing leads to an increased incidence of depression, anxiety, psychosomatic disorders, smoking, substances abuse and more delinquency in early or late maturers. In their review, Golub et al. (2008) make out a difference between internalizing disorders (depression and eating disorders) and externalizing disorders (substances abuse and conduct disorders). What are the clinical and psychological sources that allow to identify these clusters of disorders? How does this new risk, issued from timing development, cope with development paradigm derived from the Piaget's psychological mainstream insights (Turmel, 2008)? Or would a medical assessment replace the psychological one?

In more recent studies attention has been focused on puberty timing in relation to affective disorders and incidence of risk behavior in adolescence (cigarette smoking, substance abuse, multiple sexual partners, conduct disorder). How far from normal does pubertal age need to be to suggest a risk or to delineate the shift between delinquency and social and parental limits' test? To which extent are behavior risks connected to adolescence as typical "crisis age" simply brought back to preadolescence? In parallel with the large-scale studies mentioned above, many articles flourished with the aim to demonstrate how early puberty may prompt further delinquency. Beaver and Wright (2005) judge it all with the same severity: "graffiti writing, damaging property, lying to parents, shoplifting, fighting in a group, being loud and rowdy, shooting or stabbing someone, carrying a weapon to school and spending the night away from home without permission" (Beaver and Wright, 2005:175). What about juvenile delinquency as related solely to hormonal changes rather than a social transition of status and behavior to adult age in any particular context? Girls having early puberty are coupling more frequently with boys demonstrating an anti-social behavior: "Physical maturation was [...] their ticket of entry into the delinquent world of boys" (Beaver and Wright, 2005: 171). As for female preadolescents and adolescents, sleep disturbance is linked to an increased risk for pubertyrelated fatigue, sexual abuse, a higher prevalence of mental illness and sensitivity to family disruption, and increased domestic and grooming expectations (Vallido, Jackson \& O'Brien, 2009). "Mad, sad and hormonal": here we have a gendered picture of the topics presented by this literature. The anthropologist Mary Douglas (1990) argued that the use of the word "risk", rather than its former usage as a synonym for "danger" or "hazard", has a rhetorical effect of creating an aura of neutrality that cloaks the concept in scientific legitimacy. Paradoxically, this lets statements about risk be readily associated with moral approbation: for example when blaming children early puberty for behavioral misconduct. As the French sociologist Robert Castel (1991) puts it, mobilization of the concept of risk becomes a new mode of surveillance - self surveillance: in other words a component of the micro-physics of power that Foucault noted with reference to emerging neo-liberal society. Castel warns that such "hyper-rationalistic" comes with a cost and that there may be "iatrogenic aspects" to this new form of prevention among which chronic anxiety could be prominent. As Lock and Nguyen argued, the idea of being epidemiologically "at risk" is a construct of modernity: "In theory morally neutral, the notion of risk provides a means whereby experts can minimize direct intervention into people's lives, employing instead the agency of subjects in their own selfregulation through "risk management" (2010: 306). Moreover, this categorization of risk unifies self and body: risk is embodied and latent, and may be revealed if trigged by environmental factors.

\section{Normal body, social issue: the practitioners' point of view}

In passing from medical literature to the experience of interviews with health professional, the worry towards precocious puberty seems to fade. Due to different medical devices, any lexical comparison between Italian and French professionals proves hard - yet coincidences and similarities can be detected.

First of all, the 61 interviews to general practitioners, pediatricians and other health staff members record very few contacts with girls and boys between 9 and 13: the only exceptions are subjects suffering from serious diseases such as diabetes, some neoplastic forms or heavily-crippling diseases whose onset precedes preadolescence.

In Lorraine, Alsace and Venetia, all the interviewed pediatricians and general practitioners claim that children of that age seldom go to the doctor's as " they are not ill " - that is, they do not show any of the child illnesses the youngest usually suffer from. No surprise $80 \%$ patients of French pediatricians are less than 6 . The managers of state medical structures like the French or Italian Health Planning Centers (that deal with the feminine reproductive health hence with contraception, voluntary termination of pregnancy, etc.) report they seldom examine girls under 13 where 'seldom' means "less than 10 cases per year". The French school nurses, as well as the professionals who work with teenagers in the three above-mentioned regions, have more regular contacts with children from 12 to 13 years of age - thanks to programs of public prevention and teenage counseling, rather than of medical care. Both in France and in Italy, children between 9 and 13 are scarcely visible in health centers - which makes them little medicalized.

Second: none of the 61 professional informants reports any substantial age anticipation, puberty development or relevant increase in central precocious puberty. In interviews, there shows a tendency for GPs to launch off with popularized ideas and intuitive pronouncements on early puberty. Yet, when consulting data, evidence goes against representations. The following dialog reflects the average exchange between researchers and general practitioners:

M: "With me it began later, but on average it was at 13 or 14 years old. The average has dropped from 13 to ... well, I don't really know ... so I'll hazard a guess ... say, to $11 \frac{1 / 2 . "}{}$

\section{I: "So now girls start their periods at 10-11 years old?"}

M: "I don't know many girls with periods at that age [...]. Look, I saw one yesterday. She told me she had started her periods 18 months before (she looks her upon the computer). Ah, no, that can't be so! She's 14 , so she had her first period at $12 \frac{1}{2}$. Well, the girl's quite normal" (GP2, a woman, Lorraine).

Due to the unreliability of scientific data on the subject ( $c f . S u$ pra), along with the limited exposure to studies on puberty, several general practitioners and pediatricians tend to turn their 
occasionally-received ideas into a standard. Pediatricians are alone in measuring puberty according to the Marshall and Tanner scale (1969), which provides them with precise data on the pubertal development of their young patients: a group in which girls of 9-13 years old are in a minority. Notwithstanding an average 20-or-so years' practice, the general practitioners and pediatricians in Lorraine and Alsace state they have not noticed any change in the age of onset of menarche in their young patients - with the exception of only one or two cases of central precocious puberty. In parallel, no school nurse has reported any case of early puberty among the examined children of 7-8 years of age.

In Venetia, professionals report "a few cases" of early puberty or precocious puberty, and they relate them to separate causes. As confirmed by a Milanese unpublished study on both boys and girls, one of them states an increase in the cases of early thelarche and adrenarche, and associates it to bovine meat treated with hormones and mainly used for homogenized food. Another professional reports more cases of precocious puberty among adopted children - and a gynecologist of the SIGIA (the Italian Society of Child and Adolescent Gynecology) states that precocious puberty "is a well-defined medical niche. I neither know nor believe it has any sociological or statistic relevance". You can count precocious puberty researchers on the fingers of one hand:

It is an utterly specialist issue. In Italy you may have one or two specialists who do that only, examine those three cases only maybe five cases, where the hypothalamus goes its own way (Gynecologist, a woman, Venetia).

Differently from their French colleagues, Italian practitioners have shown a better knowledge of the American researches - yet they do not integrate them with their own clinical experience.

Few of the French and Italian practitioners we interviewed have met cases of truly precocious puberty, which is more usually treated by endocrinologists. Two of them, one from a large town in the East of France and another from a small hospital in a mountainous area in Venetia, have reported fewer than ten cases per year and have seen no change in numbers in fifteen years of practice. Such figures are well below the hundred cases per year reported by the French hospital centers of Necker or Montpellier - nor is it possible to understand whether these differences depend on regional peculiarities.

Third, both French and Italian specialists mark the social and psychological, rather than medical dimensions of precocious teenage. On the one hand, Alsatian and Lorraine urban professionals, as well as some school nurses and doctors stress on feminization, that is the sexualization of young girls, and mark the gap between the child's age, clothes and make-up:

Early puberty, anticipation of the onset? Have there been more instances during my 20 years of practice? There's a lot of talk about it but it's not borne out by fact. Generally, young girls start their periods between the ages of 11 and 14. No, I don't have the impression that puberty occurs at an earlier age. It's not the onset of puberty that comes earlier, it's feminization. Promoting femininity at an early age (Pediatrician 1, a woman, Alsace).

When the research dialog deepens, the professional often focuses on a couple of directly-observed cases:

Some 13 year-old girls look like the sex bombs you see in rap video-clips [...] they wear hot pants, their necklines are this low, their breasts this big, they are girls between 12 and 14 who ... They eroticize their bodies, more or less deliberately [...] Yet it is just an epiphenomenon (General practitioner, a man, Alsace).
Italian professionals are also worried with a feminization they consider precocious, yet (differently from their French colleague) they also insist on the harmful effects of nutrition and polluting agents.

When dealing with precocious adenarche or thelarche (for example, at 7 years of age), as well as with some case of central precocious puberty, the social dimensions of the French and Italian experiences prove crucial:

I am before upset parents who need to know whether to start any therapy - and then, when it all gets stopped: 'Ah!', they feel relieved. We have worked hard on it: to sleep easy, I give them a couple of years' therapy. We keep them still, we bring them to the proper age - and this is a great relief for them (PediatricianEndocrinologist 2, a man, Venetia).

\section{A French endocrinologist supports this idea:}

- You know, the ultimate risk of precocious puberty lies on two levels: precocious puberty goes with great uneasiness and relevant physical transformation; if there is a gap from this point of view, that is of great consequence among children of the same age, a very difficult psychological adaptation may well follow and result into ... it can be responsible of ultimate anxiety hence of some anxious-depressive syndrome among children and school maladjustment.

- So much for the physical effects, yet is there any physiological effect?

- [...] Let us put it like that: the output of puberty matches a physiological thrust to grow, and if this thrust comes too early... well, there is a biological clock to follow. If ... to make it easy: if a child enters very earlier in puberty, she is going to experience a very precocious growth peak; but this peak is going to be quite weak, so that her prognostic about adult size will prove shorter than what follows an average puberty development. Yet it is all both open to question and self-evident. If parents are tall, and the height prognostic is encouraging, the point has no great importance: but if we have a baby girl with a precocious puberty, without promising to be very tall as well, than this turns out relevant because a height deficit of $4,5,6 \mathrm{~cm}$ - well, this could have some aftermath on her well-being, her social inclusion, etc.". (Endocrinologist 1, a man, Alsatia)

What these health professionals state follows the mainstream of medical research, in that they focus nearly exclusively on girls and because such precocity is compared with a gap between the expected body at a certain age and the real body - as well as with the risks generated by this gap. They also refer to a prognostic medicine forecasting the size in the adult age correcting any future size considered as incapacitating before society. But the major difference is that, unlike the writing in medical literature, they do not see a large-scale advance in age at onset of puberty in girls -whatever the form, peripheral or central. They are less concerned by the medical dimension of puberty than by the social significance of the child's body - so that they watch out for the signs of dress and adornment practice that can be expected at that age.

\section{Conclusions}

The debate about the timing of puberty and the factors that are responsible for the secular trend toward an earlier puberty stems from several sources. First, the question of whether a secular trend in puberty timing actually exists is still debated between American 
researchers and American and European scientists. Second, the terms "puberty" and "puberty onset" have been used to indicate a variety of puberty markers: this has generated a confusion, further increased by the subtle semantic shift between 'precocity as disease' and 'prematurity as partial form of precocious puberty" (Buck Louis et al., 2008) in which the full spectrum of pubertal changes is absent and only specific changes occur. Third, puberty timing is a consequence of a wide range of endocrine, genetic and environmental factors. Consistent with the weight of evidence of environmental influences on puberty, reviews focus rather on endocrine-disrupting chemicals and body size than on other environmental factors - such as psychosocial ones, or the quality of relations in and out the family, at school. As we have seen, this leads to conjecture a relation between earliness and risk behavior rather than to demonstrate it.

The controversy has focused on early breast development in girls, found in American studies from the late 90s, with respect to the statistical standard medically accepted in Europe and North America. Hundreds of medical articles, and an increased control on the children clothing, along with newspaper articles in France and Italy and thousands of references on the internet, allow us to assert a moral panic around the shortening of childhood, especially child girls'. With an incipient chest at 6 or 7 years, the order of ages and gender is in question - and the stages of development that standardize childhood are upset. The medical literature and its dispersion in the press, as it is moved by female precocity, create a medical category to objectify the complex and labile process of puberty, only to result in the invention of female infant precocity.

Notwithstanding the lack of evidence in the studies and the controversies over puberty timing, a social alarm is spreading by, disseminated by press screamers. Not only are preadolescents precociously sexually active: they are prone to consumerism and substance abuse, as an imitation of adult's misconducts. Childhood is shorter and shorter, and physical signs demonstrate it.

For health scientists, the finding of a secular trend would identify a new public health concern for investigation of potential causes. In this picture, gender and race remain a conundrum: it is a cause in se (earlier puberty as gender and race dependent, in the dogma of genetic determinism), or an effect of inequality that stereotypes vulnerable groups such as poor minorities, poor immigrants, adopted children, and so on: let alone girls, which makes that inequality a gendered one. The problem of public health develops around environmental causes for the target populations. For clinicians, the finding of a secular trend could influence the normative guidelines for puberty timing. An earlier average time of puberty might lower the ages considered precocious, which in turn could potentially affect treatment protocols and increase or decrease the number of children treated.

But the differences between American and European knowledge, along with discussions among specialists of different professions, blur definitions - as the proliferation of diffuse and confused speech on "precocious puberty" creates a gap between the international literature and the practitioners, clinicians and nurses met in France and Italy, who regularly work with children next to these ages. They find neither pubertal advancement in their patient base, nor a spreading of "true precocious puberty," and they feel far from a scientific production with which they share only social stereotypes.

A one-dimension pre-adolescent is depicted in this medical literature: biologically and genetically driven, as well as precociously mature, but without any agency or competence. Human bodies are profoundly and ceaselessly influenced by environmental contexts - that is historical, social, political, economic and cultural variables. No doubt the changes in an human environment- that is pesticide use, toxic waste, and so on - are affecting every kind of living organism, humans included, at a greater rate than ever before. As a result, local social and biological variables, significant for health and illness, must be taken account of. The social trajectory whose development stages cling to age and abnormality, risk exposure and precocious sexuality, recalls Michel Foucault's pages about the construction of normalized infancy (1999): the pathologization of every kind of early puberty generates a medical narration around infancy (and pre-adolescence) which is given a pathological responsibility; thus the child is made responsible of its own body, still the real guilt is charged on its parents in terms of negligence and inadequate surveillance.

But as Foucault (1976) showed about the "dispositif de sexualité" (just like in other physiological changes such as menopause or andropause (Diasio and Vinel, 2007), the propensity of medicine to freeze a labile and unstable process into a medical category (and then into a public health problem), joins the creation of several resistance and centrifugal discourses that disturb the medicalization of preteens - only to possibly hinder their ultimate agency from living their body.

\section{Acknowledgments}

The studies on which this article is based were funded by the Agence Nationale de la Recherche, France, Grant $N^{\circ}$ ANR-09-ENFT017 'Expériences du corps et passage d'âge: le cas des 9-13 ans (France et Italie)', Acronyme: Corâge, to Nicoletta Diasio, University of Strasbourg and Virginie Vinel, University of Lorraine, Principal Investigators. We are indebted to health staffs, social services, families and children in Alsatia, Lorraine and Venetia who welcomes us and enabled our research to take place. We are grateful to our research colleagues Nicoletta Diasio, Simona De Iulio, Benoît Dejaiffe, Anne Fernandes, Caroline Hérasse, Marie-Pierre Julien, Myriam Klinger, Louis Mathiot, Simona Tersigni, Ingrid Voléry for their stimulating conversations and suggestions.

\section{References}

Armstrong, D., 1995. The rise of surveillance medicine. Sociol. Health Illn. 17 (3), 393-404.

Bailey, R., 2011. Letting Children be Children. Report of an Independent Review of the Commercialization and Sexualisation of Childhood. Presented to Parliament by the Secretary of State for Education by Command of Her Majesty, June 2011.

Beaver, K.M., Wright, J.P., 2005. Biosocial development and delinquent involvement. Youth Violence Juv. Justice 3 (2), 168-192.

Berkey, C.S., Gartner, J.D., Frazier, A.L., Colditz, G.A., 2000. Relation to childhood diet and body size to menarche and adolescent growth in girls. Am. J. Epidemiol. 152 (5), 446-452.

Biro, F.M., Greenspan, L.C., Galvez, M., Pinney, S.M., Teitelbaum, S., Windham, G., Deardorff, J., Succop, R., Hiatt, R.A., Kushi, Lawrence H., Wolff, M.S., 2013. Onset of breast development in a longitudinal cohort. Pediatrics originally published online November 4, 2013; retrieved June 2, 2014 URL. http://pediatrics. aappublications.org/.

Bouchard, P., Bouchard, N., 2003. Miroir, miroir: la précocité provoquée de l'adolescence et ses effets sur la vulnérabilité des filles. Université Laval, Québec.

Bourdieu, P., 1997. Les usages sociaux de la science. INRA éditions, Paris.

Brauner, R., Couto-Silva, A.-C., Chemaitilly, W., Adan, L., Trivin, C., 2005. Pubertés précoces centrales des filles: prédiction de l'étiologie. Arch. Pédiatr. 12, $1661-1664$

Britton, C.J., 1996. Learning about "the curse". An anthropological perspective on experiences of menstruation. Women's Stud. Int. Forum 19 (6), 645-665.

Brumberg, J.J., 1997. The Body Project: an Intimate History of American Girls. Random House, New York.

Bruni, V., Dei, M., Nori, J., Verni, A., 2001. Lo sviluppo puberale: valutazione ecografica. Medico Bambino 5, 315-318.

Buck Louis, G.M., Gray, L.E., Marcus, M., Ojeda, S.R., Peskovitz, S.O., Feldman Witchel, S., Sippel, W., Abbott, D.H., Soto, A., Tyl, R.W., Bourguignon, J.-P., Shakkebaek, N.E., Swan, S.H., Golub, M.S., Wabitsch, M., Toppari, J., Euling, S.Y., 2008. Environmental factors and puberty timing: expert panel research needs. Pediatrics 121, 192-207.

Buckingham, D., 2000. After the Death of Childhood. Growing up in the Age of Electronic Media. Polity Press, London.

Callon, M., Latour, B. (Eds.), 1991. La science telle qu'elle se fait. la Découverte, Paris. 
Carel, J.C., Linglart, A., Roger, M., Lalhou, N., Chaussain, J.L., 2002. Quand et comment traiter une puberté précoce centrale. Arch. Pédiatr. 9, 237-239.

Cartault, A., Edouard, T., Pienkowski, C., Tauber, M., 2008. Puberté normale. La rev. du prat. 58, 1311-1316.

Castel, R., 1991. From dangerousness to risk. In: Burchell, G., Gordon, C., Miller, P. (Eds.), The Foucault Effect: Studies in Governmentality. University of Chicago Press, Chicago, Illinois, pp. 281-298.

Chebel, M., 1984. Le corps en Islam. PUF, Paris.

Cohen, S. (Ed.), 2004. Folk Devils and Moral Panics. The Creation of the Mods and Rockers, third ed. Routledge, Oxon-New York.

Colon, I., Caro, D., Bourdony, C.J., Rosario, O., 2000. Identification of phtalate esters in the serum of young Puerto Rican girls with premature breast development. Environ. Health Perspect. 108 (9), 895-900.

Cook, D.T., Kaiser, S.B., 2004. Betwixt and Between. Age ambiguity and the sexualization of the female consuming. J. Consumer Cult. 4 (2), 203-227.

Corsaro, W., 1997. The Sociology of Childhood. Pine Forge Press, Thousand Oaks California.

Cozzi, D., 2013. Mad, sad and hormonal. Riflessioni sul corpo dei preadolescenti e la costruzione dei saperi medici, AM. Riv. della Soc. Ital. Antropol. Med. 35-36, $151-186$.

Cozzi, D., 2014. Corps en réseau. Jeunes et sexualité dans des sites internet à Strasbourg et Feltre (Vénétie). Rev. Des. Sci. Soc. 51, 34-43.

de Vries, J., 2007. The obesity epidemics: medical and ethical consideration. Sci. Eng. Ethics 13, 55-67.

Diasio, N., Vinel, V. (Eds.), 2007. Il tempo incerto. Antropologia della menopausa. Franco Angeli, Milano.

Diasio, N., Vinel, V. (Eds.), 2014. La préadolescence existe-t-elle?. Rev. Sci. Soc, 51.

Diasio, N., 2012. Maillage des temps et gouvernement des corps dans la construction des rapports d'âge et de genre. SociologieS. Retrieved May 25, 2014. URL http://sociologies.revues.org/4118.

Dimartino-Nardi, J., 1999. Premature adrenarche: findings in prepubertal African-American and Caribbean-Hispanic girls. Acta Paediatr. Suppl. 88 (433) $67-72$.

Douglas, M., 1990. Risk as a forensic resource. Daedalus 119, 1-16.

Duquet, F., Quiéniart, A., 2009. Perceptions et pratiques de jeunes du secondaire face à l'hypersexualisation et à la sexualisation. Rapport de recherche projet : Outiller les jeunes face à l'hypersexualisation », UQAM, YWCA, Forum Jeunesse de l'île de Montréal. Retrieved September 12, 2013 URL: http://www.er.uqam. ca/nobel/jeunes/rapport.recherche.texte.pdf.

Euling, S.Y., Herman-Giddens, M.E., Lee, P.A., Selevan, S.G., Juul, A., Sørensen, T.I.A Himes, J.H., Teilman, G., Swan, S.H., 2008. Examination of US puberty-timing data from 1940 to 1994 for secular trends: panel findings. Pediatrics 121, S172-S191.

Fabiani, J.-L., 1997. Controverses Scientifiques, Controverses Philosophiques Enquête,5, put on-line 15 July 2013, retrievedAugust 26, 2013. URL: http:/ enquete.revues.org/1033.

Fassin, D., Memmi, D. (Eds.), 2004. Le gouvernement du corps. Editions EHESS, Paris.

Fingerson, L., 2005. Agency and the body in adolescent menstrual talk. Childhood $12(1), 91-110$

Foucault, M., 1976. Histoire de la sexualité. In: La volonté de savoir, Tome 1. Gallimard, Paris.

Foucault, M., 1999. Les Anormaux. In: Cours au collège de France, 1974-1975. Gallimard, Seuil, Paris.

Galland, O., 2008. Une nouvelle adolescence. Rev. française sociol. 49 (4), 819-826.

Gardey, D., Löwy, I. (Eds.), 2000. L'invention du naturel. Les sciences et la fabrication du féminin et du masculin. EAC, Paris.

Gasparini, N., Di Maio, S., Greco, L., 2005. I tempi della pubertà spontanea nelle femmine: uno studio campano. Quad. ACP 12 (2), 85-86.

Gaudineau, A., Ehlinger, V., Vayssière, C., Jouret, B., Arnaud, C., Godeau, E., 2010. Age la ménarche: résultats français de l'étude health behaviour in school-aged children. Gynecol. obstét. Fertil. 38, 385-387.

Goldstein, J.R., 2011. A secular trend toward earlier male sexual maturity: evidence from shifting ages of male young adult mortality. PLoS One 6 (8), e14826. http:/ dx.doi.org/10.137/journal.pone.0014826.

Golub, M.S., Collman, G.W., Foster, P.M.D., Kimmel, C.A., Rajpert-De Meyts, E. Reiter, E.O., Sharpe, R.M., Skakkebaek, N.E., Toppari, J., 2008. Public health implications of altered puberty timing. Pediatric 121, S218-S230.

Grumbach, M.M., Styne, D.M., 2003. Puberty: ontogeny, neuroendocrinology, physiology and disorders. In: Larsen, P.R., Kronenberg, H.M., Melmed, S. Polonsky, K.S. (Eds.), Williams Textbook of Endocrinology, tenth ed. WB Saunders, Philadelphia, pp. 1115-1286.

Henley, D.V., Lipson, N., Korach, K.S., Bloch, C.A., 2007. Prepubertal gynecomastia linked to lavender and tea tree oils. New Engl. J. Med. 356 (5), 479-485.

Herman-Giddens, M.E., Slora, E.J., Wasserman, R.C., Bourdony, C.J., Bhapkar, M.V., et al., 1997. Secondary sexual characteristics and menses in young girls seen in office practice: a study front the pediatric research in office setting network. Pediatrics 99, 505-512.

Herman-Giddens, M.E., Wang, L., Koch, G., 2001. Secondary sexual characteristics in boys: estimates from the National Health and Nutrition Examination Survey III, 1988-1994. Archives Pediatr. Adolesc. Med. 155 (9), 1022-1028.

Ibañez, L., Dimartino-Nardi, J., Potau, N., Saenger, P., 2000. Premature adrenarche: normal variant or forerunner of adult disease? Endocr. Rev. 21 (6) $671-696$.

Ibañez, L., Potau, N., François, L., De Zegher, F., 1998. Precocious pubarche, hyperinsulinism and ovarian hyperandrogenism in girls: relation to reduced fetal growth. J. Clin. Endocrinol. Metab. 83 (10), 3558-3562.
INSERM, 2007a. Croissance et puberté. Evolutions séculaires, facteurs environnementaux et génétiques. Inserm, Expertise Collective, Paris.

INSERM, 2007b. Synthèse. Croissance et puberté. Evolutions séculaires, facteurs environnementaux et génétiques. Inserm, Expertise Collective, Paris.

James, A., Prout, A. (Eds.), 1990. Constructing and Reconstructing Childhood. Contemporary Issues in the Sociological Study of Childhood. Falmer Press, London.

James, A., Jenks, C., Prout, A., 1998. Theorizing Childhood. Polity Press, Cambridge.

Jouanno, C., 2012. Contre L'hypersexualisation. Un Nouveau Combat Pour L'égalité Rapport parlementaire, mars, retrieved April 24, 2012 URL. http://www.socialsante.gouv.fr/IMG/pdf/rapport_hypersexualisation2012.pdf.

Juul, A., Teilmann, G., Scheike, T., Hertel, N.T., Holm, K., Laursen, E.M., Main, K.M., Skakkebaek, N.E., 2006. Pubertal development in Danish children: comparison of recent European and US data. Int. J. Androl. 29 (1), 247-255.

Kaltiala-Heino, R., Kosunen, E., Rimpela, M., 2003a. Pubertal timing, sexual behavior and self-reported depression in middle adolescence. J. Adolesc. 26 (5), 531-545.

Kaltiala-Heino, R., Rimpela, M., Rissanen, A., Rantanen, P., 2003b. Early puberty and early sexual activity are associated with bulimic-type eating pathology in middle adolescence. J. Adolesc. Health 28 (4), 531-545.

Kaltiala-Heino, R., Marttunen, M., Rantenen, P., Rimpela, M., 2003c. Early puberty is associated with mental health problems in middle adolescence. Soc. Sci. \& Med. 57 (6), 1055-1064.

Kaplowitz, P., 2004. Extensive personal experience. Clinical characteristics of 104 children referred for evaluation of precocious puberty. J. Clin. Endocrinol. Metabolism 89 (8), 3644-3650.

Kaplowitz, P., Oberfield, S., 1999. Reexamination of the age limit for defining when puberty is precocious in girls in the United States: implications for evaluation and treatment. Pediatrics 104 (4), 936-941.

Kaplowitz, P., Kemp, S., 2013. Precocious puberty. Medscape. Retrieved June 10, 2014 URL. http://emedicine.medscape.com/article/924002-overview.

Karpati, A.M., Rubin, C.H., Kieszak, S.M., Marcus, M., Troiano, R.P., 2002. Stature and pubertal stage assessment in: American boys: the 1988-1994 Third National Health and Nutrition Examination Survey. J. Adolesc. Health 30 (3), 205-212.

Kaufert, P., Gilbert, P., 1986. Women, menopause and medicalization. Cult. Med. Psychiatry 10 (1-5), 7-21.

Kraus, C., 2000. La bicatégorisation par sexe à l'épreuve de la science. Le cas des recherches en biologie sur la détermination du sexe chez les Humains. In: Gardey, D., Löwy, I. (Eds.), L'invention du naturel. Les sciences et la fabrication du féminin et du masculin. EAC, Paris, pp. 187-213.

Laqueur, T., 1990. Making Sex: Body and Gender from the Greeks to Freud. Harvard UniversityPress, Cambridge.

La Rochebrochard (de), E., 1999. Les âges à la puberté des filles et des garçons en France. Mesure à partir d'une enquête sur la sexualité des adolescents. Population 6, 933-962.

Lock, M., 1993. Encounters with Aging: Mythologies of Menopause in Japan and North-America. University of California Press, Los Angeles, Berkeley.

Lock, M., Nguyen, V.-K., 2010. An Anthropology of Biomedicine. Wiley-Blackwell, Oxford.

Löwy, I., 2009. L'âge limite de la maternité: corps, biomédecine, et politique. Mouvements 3 (59), 102-112.

Mardon, A., 2009. Les premières règles des jeunes filles : puberté et entrée dans l'adolescence. Soc. Contemp. 75 (3), 109-129.

Maroteaux, P., 2008. Du danger d'être petit. Une taille inférieure à la moyenne devient-elle pathologique dans notre société? Arch. pédiatr. 15, 1381-1382.

Marshall, W.A., Tanner, J.M., 1969. Variations in pattern of pubertal changes in girls. Archives Dis. Child. 44, 291-303.

Marshall, W.A., Tanner, J.M., 1970. Variations in pattern of pubertal changes in boys. Archives Dis. Child. 45, 13-23.

Martin, E., 1992. The Woman in the Body. A Cultural Analysis of Reproduction, revised ed. Bacon Press, New York.

Martin, E., 2007 [1991]. The egg and the sperm: how science has constructed a romance based on stereotypical male-female roles. In: Lock, M., Farquhar, J. (Eds.), Beyond the Body Proper. Duke University Press, pp. 417-427.

Meyrowitz, J., 1985. No Sense of Place. The Impact of Electronic Media on Social Behavior. Oxford University Press, New York.

Moffat, T., 2010. The "Childhood obesity epidemic": health crisis or social construction. Med. Anthropol. Q. 24 (1), 1-21.

Mora, R., 2012. "Do it for all your pubic hairs!": Latino boys, Masculinity, and puberty. Gender Soc. 26 (3), 433-460.

Moulinié, V., 1998. La chirurgie des âges. Corps, sexualité et représentations du sang. Éditions de la Maisons des Sciences de l'Homme, Paris.

Neiterman, E., 2010. The Embodied Experiences of Pregnancy: Learning, Doing and Attaching Meaning to Pregnant Body in Different Social Context, vol. 1. ETD Collection for McMaster University, pp. 10-23.

Palmert, M.R., Malin, H.V., Boepple, P.A., 1999. Unsustained or slowly progressive puberty in young girls: initial presentation and long-term follow-up of 20 untreated girls. J. Clin. Endocrinol. Metab. 84 (2), 415-423.

Palmert, M.R., Boepple, P.A., 2001. Variation in the timing of puberty: clinical spectrum and genetic investigation. J. Clin. Endocrinol. Metab. 86 (6), 2364-2368.

Parent, A.-S., Teilmann, G., Juul, A., Sakkebaek, N., Toopari, J., Bourguignon, J.-P., 2003. The timing of normal puberty and the age limits of sexual precocity: variations around the world, secular trends and changes after migration. Endocr. Rev. 24 (5), 668-693. 
Pienkowski, C., Granjean, S., 2008. La puberté avant l'âge. Nouveaux aspects. IPSEN retrieved March 4, 2013 URL. http://www.medecine.ups-tlse.fr/desc/fichiers/ Puberte\%20precoce.pdf.

Rennes, J., Achin, C., Ouardi, S., Burgi, N., Bessin, M., 2009. Introduction au dossier: La tyrannie de l'âge. Mouvements 3 (59), 7-10.

Rigon, F., De Sanctis, V., Bernasconi, S., Bianchin, L., Bona, G., Bozzola, M., Buzi, F. Radetti, G., Tatò, L., Tonini, G., De Sanctis, C., Perissinotto, E., 2012. Menstrual pattern and menstrual disorders among adolescents: an update of the Italian data. Ital. J. Pediatr. 38, 38. www.ijonline.net/content/38/1/38.

Roberts, C., 2013. Early puberty, 'sexualization' and feminism. Eur. J. Women's Stud. 20 (2), 138-154.

Sinha, S., Kemp, S., 2013. Precocious pseudopuberty. Medscape. Retrieved June 10, 2014 URL. http://emedicine.medscape.com/article/923876-overview.

Sopher, A.B., Thornton, J.C., Silfen, M.E., 2001. Prepubertal girls with premature adrenarche have greater bone mineral content and density than controls. J. Clin. Endocrinol. Metab. 86 (11), 5269-5272.

Sørensen, K., Mouritsen, A., Aksglaede, L., Hagen, Casper P., Mogensen, S., Juul, A., 2012. Recent secular trends in pubertal timing: implications for evaluation and diagnosis of precocious puberty. Horm. Res. Paediatr. 77, 137-145.
Turmel, A., 2008. A Historical Sociology of Childhood. Developmental Thinking, Categorization and Graphic Visualisation. Cambridge University Press, Cambridge.

Vallido, T., Jackson, D., O'Brien, L., 2009. Mad, sad and hormonal: the gendered nature of adolescent sleep disturbance. J. Child Health Care 13 (1), 7-18.

Vinel, V., 2014a. Controverses médicales autour de la puberté: précocité féminine et invisibilité masculine. Rev. Sci. Soc. 51, 64-73.

Vinel, V., 2014b. De la naturalisation des différences de genre à l'individualisation des corps: regards de professionnels de santé sur la puberté. In: SinigagliaAmadio, S. (Ed.), Enfance et genre. Presses Universitaires de Lorraine, Nancy, pp. 205-223.

Voléry, I., 2014. Gouverner la sortie de l'enfance par ses marges ? Les figures du caïd-de-cité et de la fille-de-quartier dans les espaces de l'animation socioculturelle. Rev. Sci. Soc. 51, 82-91.

Wichstrøm, L., 1995. Social, psychological and physical correlates of eating problems: a study of the general adolescent population in Norway. Psychol. Med. 25 (3), 567-569.

Williams, J.M., Dunlop, L.C., 1999. Pubertal timing and self-reported delinquency among male adolescents. J. Adolesc. 22 (1), 157-171. 